Asian J. Med. Biol. Res. 2016, 2 (2), 274-278; doi: 10.3329/ajmbr.v2i2.29071

\author{
Asian Journal of \\ Medical and Biological Research \\ ISSN 2411-4472 (Print) 2412-5571 (Online) \\ www.ebupress.com/journal/ajmbr
}

\title{
Article \\ Study on effect of different levels of concentrate on growth performance of both male and female lamb
}

\author{
Masum Billah $^{1^{*}}$, Md. Humayun Kabir ${ }^{2}$, Md. Hafizur Rahman ${ }^{2}$ and Md. Abdul Hamid ${ }^{1}$ \\ ${ }^{1}$ Department of Animal Science \& Nutrition, Hajee Mohammad Danesh Science \& Technology University, \\ Dinajpur, Bangladesh \\ ${ }^{2}$ Animal Health Research Division, Bangladesh Livestock Research Institute, Savar, Dhaka-1341, Bangladesh \\ ${ }^{*}$ Corresponding author: Masum Billah, Department of Animal Science \& Nutrition, Hajee Mohammad Danesh \\ Science \& Technology University, Dinajpur, Bangladesh. E-mail: masumdvm@gmail.com
}

Received: 07 June 2016/Accepted: 23 June 2016/ Published: 30 June 2016

\begin{abstract}
The present study was carried out to assess the effect of concentrate on growth performances of both male and female lamb. For this purpose twenty four (12 male and 12 female) lamb aged about 5-6 months were selected and divided into three groups (Treatment group T1, T2 and control group T0). In each group having 4 males and 4 females lamb, all lambs were supplied green roughages ad-libitum, control group T0 was allowed no concentrate and treatment group T1 \& T2 were supplied 100 gm \& 200 gm concentrate mixture respectively for 90 days experimental period. Animals were weighed at 15 days interval. Significant differences of live weight gain among these three groups were found. Allowing $100 \mathrm{gm}$ (T1) concentrate mixture along with green grass improved growth rate in both male and female lamb. Increasing of concentrate supplementation improved live weight gain (found in T2 group). Total live weight gain $(\mathrm{kg})$ and average daily live weight gain $(\mathrm{g} / \mathrm{d})$ were $4.25 \pm 0.52 \mathrm{~kg}$ and $47.20 \pm 5.75 \mathrm{~g}, 5.38 \pm 0.83 \mathrm{~kg}$ and $59.73+9.17 \mathrm{~g}$ and $7.00 \pm 0.54 \mathrm{~kg}$ and $77.78 \pm 6.00 \mathrm{~g}$ in male lambs and $2.25 \pm 0.21 \mathrm{~kg}$ and $25.00 \pm 2.34 \mathrm{~g}, 3.18 \pm 0.32 \mathrm{~kg}$ and $35.39 \pm 3.63 \mathrm{~g}$ and $3.81 \pm 0.24 \mathrm{~kg}$ and $42.33 \pm 2.77 \mathrm{~g}$ in female lambs for the To, T1 and T2 groups respectively. Live weight was significantly $(\mathrm{P}<0.05)$ higher in male than female lambs. The results showed that $100 \mathrm{~g}$ concentrate supplementation with green roughages improved growth rate in lambs (male and female) under stall feeding condition. Increase of supplementation might improve nutrients supply to promote higher live weight gain.
\end{abstract}

Keywords: concentrate; growth; lambs

\section{Introduction}

Livestock plays a potential role in the national economy of Bangladesh. Among the livestock, sheep population is the lowest in Bangladesh. They are sparsely distributed all over the country except in the districts of greater Rajshahi, Tangail and in the delta region of Noakhali (Rahman, 1989). The population of sheep in the world, Asia and Bangladesh are about 1087.04, 436.188 and 3.2 million respectively (FAO, 2003). As a multipurpose animal, sheep provide meat, milk, wool and skin. The most important characteristics of sheep are prolificacy lambing twice a year where twinning is common (Rahman, 1989). Sheep can easily be maintained under rural conditions because of their ability to adapt to harsh environment, poor management and feeding practices. But the genetic potentialities of these sheep are deteriorating day by day due to indiscriminate rearing practices including feeding practices which in turn results in severe economic losses. Sheep mainly thrives on natural grasses available on the fallow land, roadsides, crop field, ridges and canal sites. These feed resources are characterized by low digestibility, low energy and low protein content into deficient in the minerals and vitamins (Pandit, 2005; Minson, 1967). Conventional feeding system is inadequate and need supplementation to basal diet. The supplementation of basal diet can provide more nutrients to the sheep (Kochapakdee et al., 1994; Mahajan et al., 1976). They also reported that grazing alone may not be sufficient for optimizing live weight 
gain and wool production. Concentrate supplements are needed to obtain higher intake of nutrients required for higher production (Schiene and Ibrahim, 1986).

Supplementation of concentrate with natural grasses is rarely practiced for feeding sheep in our country. Wheat bran, rice polish, soybean meal and other concentrates are available, may easily be used as supplements in growing sheep for better performance. In scavenging type of rearing, a small amount of concentrate may be supplemented to increase the productivity of sheep at the minimum cost.

Keeping this view in mind, the present experiment was undertaken with the following objectives:

(a) To study the effect of supplementing different levels of concentrate on growth performance of both male and female lamb.

(b) Comparative growth performance of male and female lamb with different level of concentrate along with adlibitum green grasses.

(c) To determine the optimum level of concentrate supplementation with the natural grasses for meeting the nutrient requirement for sheep.

\section{Materials and Methods}

The experiment was conducted during February to May 2015 (90 days) to study the effect of concentrate supplementation on growth of male and female sheep.

\subsection{Experimental site}

This experiment was conducted at Boalia and Ashikpur area of Tangail sadar upazilla,Tangail.

\subsection{Selection of lamb}

A total of 24 lambs of both sexes (12 male and 12 female lambs) were selected from the Boalia and Ashikpur areas of Tangail sadar upazilla. The age of these lambs were between 5-6 months and their initial live weights on average were 9.84 for male and 8.67 for female lambs. Lambs were selected from 12 farmer's house (1 male and 1 female lamb from each farmar`s house) for this experiment. The lambs were identified with tag no. Feces of each lamb were examined for parasitic infestation and all the animals were dewormed with commercial anthelmentic drug before the start of this experiment.

\subsection{Housing and management}

The size of the each house was $4 \mathrm{ft} \times 6 \mathrm{ft}$ and made by locally available materials (bamboo, wood, gunny bag, rope, straw, dry banana leaves, nut tree leaves, coconut tree leaves and polythene). Two lambs (1 male and 1 female) were kept in each house. The floor, feeder and water trough were cleaned every day thoroughly. Separate feeders were used for roughage and concentrate feeding. Fresh drinking water was made available in bucket at all time. The animals were observed regularly for any abnormalities and disease symptom.

\subsection{Preparation of concentrate mixture}

The concentrate (wheat bran, rice polish, soybean meal) were purchased from the local market. The concentrate mixture was prepared by mixing wheat bran, rice polish, soybean meal, mineral supplement and common salt at the rate of 50: 30: 18: 1: 1 respectively. In addition, Vitamin-Mineral-Premix was mixed with concentrate mixture (@ $1 \mathrm{~g} / \mathrm{kg}$ mixed feed. The green roughage was composed of road-side grass, jackfruit tree leaves and neem leaves.

\subsection{Experimental design and dietary treatment}

The design of the experiment, number of lambs, experimental period and average initial live weight of lambs is shown in Table 1. The lambs of both sexes (12 male and 12 female) were divided into three treatments groups (To, T1 and T2) allocating 4 male lambs and 4 female lambs in each treatment. Control group (To) was allowed only green roughages ad-libitum without concentrate. The treatment groups T1 and T2 were supplied with concentrate at the rate of $100 \mathrm{~g}$ and $200 \mathrm{~g}$ per head per day respectively. The design of experiment was Completely Randomized Design (CRD). 
Table1. Experimental layout.

\begin{tabular}{llll}
\hline \multirow{2}{*}{ Parameters } & \multicolumn{2}{c}{ Dietary treatment } \\
\cline { 2 - 4 } & T0 & T1 & T2 \\
\hline Number of male lambs & 4 & 4 & 4 \\
Number of female lambs & 4 & 4 & 4 \\
Duration of the trial (days) & 90 & 90 & 90 \\
Initial live weight (male) & $10.25 \pm 0.43$ & $9.88 \pm 0.43$ & $9.38 \pm 0.37$ \\
Initial live weight(female) & $8.06 \pm 0.47$ & $9.13 \pm 0.47$ & $8.81 \pm 0.52$ \\
\hline
\end{tabular}

Here, $\mathrm{To}=$ Only green roughages (road-side grass + jackfruit tree leaves + neem leaves, ad-libitum); T1=Green roughages $+100 \mathrm{~g}$ concentrate; $\mathrm{T} 2=\mathrm{Green}$ roughages $+200 \mathrm{~g}$ concentrate

\subsection{Methods of feeding}

The concentrate mixture was offered to the lambs two times daily. Half of the total amount of concentrate mixture was offered in the morning at 8:30 am and another half of the concentrate mixture was given in the evening at 4:30 pm. The green roughage was offered to the lamb's ad-libitum. Before supplying feed to the animals, feed refusal of the previous day was collected and weighed every morning.

\subsection{Measuring of live weight}

The initial live weight of each animal was recorded by taking average weight of two consecutive days. During the experimental period, the animals were weighed at 15 days interval before supplying morning feed by using digital balance. Live weight change was calculated by subtracting the initial live weight from the final live weight. The daily live weight change was calculated by dividing the total live weight change by the number of days the experiment continued.

\subsection{Statistical analysis}

All data related to live weight gain were analyzed by using analysis of covariance (ANOCOVA) and initial live weight was analyzed by using analysis of variance (ANOVA) following a Completely Randomized Design (CRD) and the mean values with standard error of difference (SED) were recorded. Least significant difference (LSD) test was also done to compare the treatment means for different parameters by using "MSTAT" statistical program.

\section{Results and Discussion}

The main values for total live weight gain in lambs fed diets supplemented with different levels of concentrate are presented in Table 2. The average live weight gains in different treatments were $4.25 \pm 0.52 \mathrm{~kg}$ (To), $5.38 \pm 0.83 \mathrm{~kg}$ (T1) and $7.00 \pm 0.54 \mathrm{~kg}(\mathrm{~T} 2)$ in male lambs and $2.25 \pm 0.21 \mathrm{~kg}(\mathrm{To}), 3.18 \pm 0.32 \mathrm{~kg}(\mathrm{~T} 1)$ and $3.81 \pm 0.24 \mathrm{~kg}$ (T2) in female lambs, respectively. Significant difference $(\mathrm{P}<0.05)$ was observed in live weight gains for both male and female lambs. The cumulative live weight gain $(\mathrm{kg})$ observed during the experimental period is shown in Figure 1 in case of male lambs and Figure 2 in case of female lambs. Gradual increase in the live weight was observed in To, T1 and T2. Figure 2 illustrated that higher live weight gain was observed in male lambs compared to female lambs given supplemented diet. Average daily live weight gain (LWG) was $47.20 \pm 5.79 \mathrm{~g}, 59.73 \pm 9.17 \mathrm{~g}$ and $77.78 \pm 6.00 \mathrm{~g}$ in male lambs and $25.00 \pm 2.34 \mathrm{~g}, 35.39 \pm 3.63 \mathrm{~g}$ and $42.33 \pm 2.77 \mathrm{~g}$ in female lambs for the treatment groups To, T1, T2 respectively. The average daily live weight gain (LWG) of supplemented groups increased significantly $(\mathrm{P}<0.05)$ over control in both male and female lambs suggested positive response of supplementation. The findings were similar to the reports of Mazumder (1996) who indicated that average daily live weight gain (LWG) were $15.71 \mathrm{~g}, 22.66 \mathrm{~g}, 32.60 \mathrm{~g}$ and $40.47 \mathrm{~g}$ for the treatment groups To (no concentrate) T1 (100gm concentrate), T2 (200gm concentrate) and T3 (300gm concentrate) respectively.

Marked significant difference between sexes was observed in live weight gain. Similar results were reported by Normand et al. (1999) who reported that live weight gain in different groups were 46.7, 324 and 32.3 in males and 26.4, 26.7 and $29.4 \mathrm{~g} / \mathrm{d}$ in female respectively. But Majumder (1996) showed no significant difference between sexes observed in live weight gain.

Siviah and Mudaliar (1977) reported that crossbred Merino Deceani lamb receiving concentrate diet (200 g/h/d) gained $44 \mathrm{~g} / \mathrm{d}$ while Lambs on control diet (100\% roughage) gains only $13.5 \mathrm{~g} / \mathrm{d}$. Similarly, Kochapakdee et al. (1994) reported that the Thai female growing goats received concentrate diet $(0.75 \% \mathrm{BW})$ gained $36 \mathrm{~g} / \mathrm{d}$ while 
goats on control diet (grazing only) gained $15 \mathrm{~g} / \mathrm{d}$. The growth rate of lambs recorded in the present experiment was often similar than these recorded in previous studies.

Table 2. Effect of concentrate supplementation on growth performance of lambs.

\begin{tabular}{|c|c|c|c|c|c|c|}
\hline \multirow{2}{*}{ Parameter } & \multirow{2}{*}{ Sex } & \multicolumn{3}{|c|}{ Treatments } & \multirow[t]{2}{*}{ SED } & \multirow{2}{*}{$\begin{array}{l}\text { Level of } \\
\text { sig. }\end{array}$} \\
\hline & & $\overline{\text { To }}$ & T1 & $\mathbf{T 2}$ & & \\
\hline \multirow{2}{*}{ Initial live weight (kg) } & Male & $10.25 \pm 0.43$ & $9.88 \pm 0.43$ & $9.38 \pm 0.97$ & 0.93 & NS \\
\hline & Female & $8.06 \pm 0.47$ & $9.13 \pm 0.47$ & $8.81 \pm 0.52$ & 0.97 & NS \\
\hline \multirow{2}{*}{ Final live weight (kg) } & Male & $14.50 \mathrm{~b} \pm 0.89$ & $15.25 \mathrm{ab} \pm 1.5$ & $16.38 \mathrm{a} \pm 1.43$ & 0.60 & $* *$ \\
\hline & Female & $10.31 \mathrm{~b} \pm 0.57$ & $12.31 \mathrm{ab} \pm 0.53$ & $12.63 \mathrm{a} \pm 0.48$ & 0.38 & $* *$ \\
\hline \multirow{2}{*}{ Total live weight gain(kg) } & Male & $4.25 b \pm 0.52$ & $5.38 \mathrm{ab} \pm 0.83$ & $7.00 \mathrm{a} \pm 0.54$ & 0.81 & $*$ \\
\hline & Female & $2.25 \mathrm{~b} \pm 0.21$ & $3.18 \mathrm{ab} \pm 0.32$ & $3.81 \mathrm{a} \pm 0.24$ & 15.94 & $* *$ \\
\hline \multirow{2}{*}{ Avg. live weight gain $(g / d)$} & Male & $47.20 \mathrm{~b} \pm 5.75$ & $59.73 \mathrm{ab} \pm 9.17$ & $77.78 \mathrm{a} \pm 6.00$ & 10.12 & $*$ \\
\hline & Female & $25.00 \mathrm{~b} \pm 2.34$ & $35.39 \mathrm{ab} \pm 3.63$ & $42.33 a+2.77$ & 4.19 & $* *$ \\
\hline
\end{tabular}

Here, To $=$ Green roughages ad-libitum; $\mathrm{T} 1=100 \mathrm{~g}$ concentrate + green roughages ad-libitum; $\mathrm{T} 2=200 \mathrm{~g}$ concentrate + green roughages ad-libitum; $\mathrm{SED}=$ Standard error of differenc; $\mathrm{SE}=$ Standard error; $\mathrm{ab}=$ Data having dissimilar superscripts differ significantly; $* *=$ Significant at $\mathrm{P}<0.01 ; *=$ Significant at $\mathrm{P}<0.05$

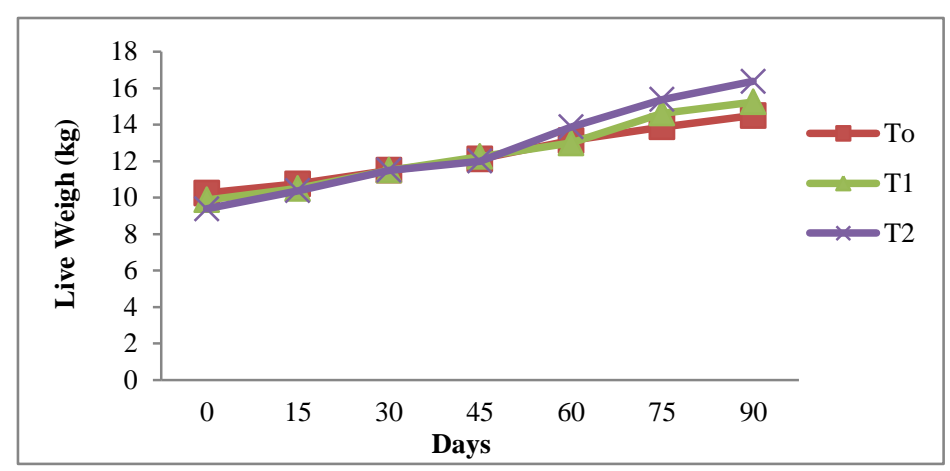

Here, To $=$ Green roughages ad-libitum; $\mathrm{T} 1=100 \mathrm{~g}$ concentrate + green roughages ad- libitum; $\mathrm{T} 2=200 \mathrm{~g}$ concentrate + green roughages ad-libitum

Figure 1. Cumulative live weight (kg) of male lambs throughout the experimental period.

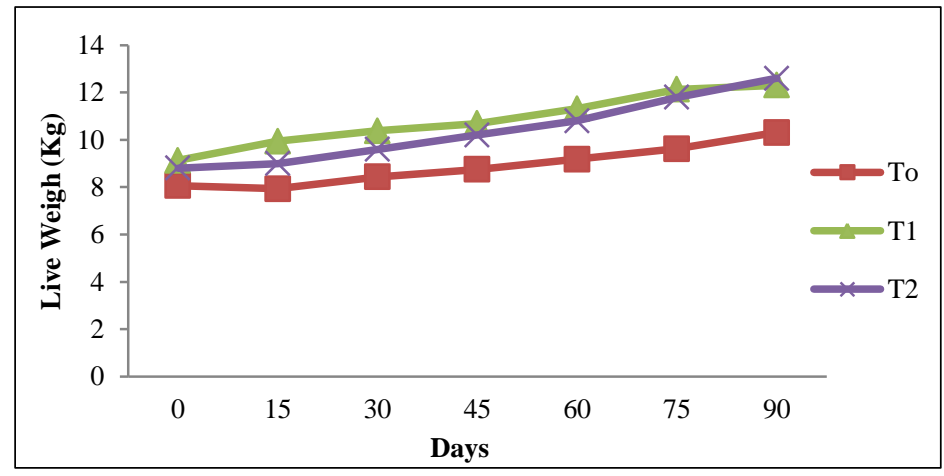

Here, $\mathrm{To}=$ Green roughages ad-libitum; $\mathrm{T} 1=100 \mathrm{~g}$ concentrate + green roughages ad- libitum; $\mathrm{T} 2=200 \mathrm{~g}$ concentrate + green roughages ad-libitum

Figure 2. Cumulative live weight $(\mathrm{kg})$ of female lambs throughout the experimental.

Umoh and Halilu (1992) reported that Balami rams about $17 \mathrm{~kg}$ were given an all concentrate diet or given concentrate to provide $75,50,25$ or 0 percent of their feed intake. Average daily gains $(\mathrm{kg} / \mathrm{day})$ were 0.160 , $0.20,0.130$ and $0.06 \mathrm{~kg}$ for rams on the 4 diets respectively. Gains and average daily gains were significantly increased for rams on the $75 \%$ supplement compared with control $(0 \%)$ or $25 \%$ supplement. 


\section{Conclusions}

The results showed that $100 \mathrm{~g}$ concentrate supplementation with green roughages improved growth rate in lambs (male and female) under stall feeding condition. Increase of supplementation might improve nutrients supply to promote higher live weight gain. Further studies with different levels of concentrate supplementation may be carried out related to growth performance for more specific recommendation.

\section{Conflict of interest}

None to declare.

\section{References}

FAO. 2003. Production Yearbook, Food and Agriculture Organization of the United Nations, Rome, Italy. 57:207-216.

Kochapakdee S, W Pralomkam, S Saithanoo, A Lawpetchara and BW Morton, 1994. Grazing management studies with Thai goats: 1 . Productivety of female goats grazing newly established pasture withvarying levels of supplementary feeding. Asain-Aust. J. Anim. Sci., 7: 289-293.

Mahajan JM, DS Chauhan and VPS Tomar, 1976. Effect of supplementary feeding to grazing on growth and wool production in sheep. Indian J. Anim. Res., 10: 90-92.

Mazumder MAR, 1996. Effect of levels of concentrate on growth and carcass characteristics in grazing sheep. M.Sc. Thesis. Dept. of Animal Science Bangladesh Agricultural University, Mymensingh.

Minson DJ, 1967. The voluntary intake and digestibility in sheep of chopped and pelleted digeatria decumbers (pangole grass) following a late application of fertilizer nitrogen. Br. J. Nutri., 2421: 587-597.

Normand J, M Theriez, P Bas, B Aurousseau, and D Sauvant, 1999. Effect of energy source, cereals vs. sugar beef pulp, on growth performance and carcass quality of intensively reared lambs. Annales-de-Zootechnie, 48: 367-380.

Pandit, A. 2005. A comparative study on performance of sheep and goats supplemented with urea molasses multinutrient block (UMMB) and sesbania leaf based UMMB. M. Sc. Thesis. Dept. of Animal Nutrition. BAU, Mymensingh.

Rahman MM, 1989. Sheep production and development in Bangladesh. Proceeding of the workshop on sheep production in Asia. PCARRD. Los Banos. Philippines. pp. 81-95.

Schiere JB and MNM Ibrahim, 1986. Supplementation of straw ration; a practical approach poceedings of rice straw and related feeds in ruminants rations; In Workshop Kandy, Srilanka, Publication No. 2. Straw utilization project, pp. 275-278.

Siviah K and ASR Mudaliar, 1977. Effect of feeding concentrates at different levels on growth rate and feed efficiency in lambs. Indian J. Anim. Res., 11: 87-90.

Uinoh BI and SAD Helilu, 1992. Effect of concentrate supplementation to browsing on performance of growing rams in a semi-arid environment. Small Rumin. Res., 9: 173-180. 